\title{
Theological Thinking Abû al-Ḥasan 'Alî al-Hasani al-Nadwî
}

\section{Sori Monang}

Universitas Islam Negeri Sumatera Utara, Medan, Indonesia

Email:wahyuwijiutomox@gmail.com

\begin{abstract}
:
The aims of this study to find out the theological Thinking Abû al-Hasan 'Alî al-Hasani alNadwî. The result in this study shows that Al-Nadwî is a great Ulama with a very complex socio-cultural background, born during the colonial era and struggling in a period of development transition and national change that makes al-Nadwî rich in various experiences of obstacles, be they social, cultural, or religious obstacles. Therefore it is not surprising that alNadwî grew up as a Fundamentalist Ulama. He is a Ulama figure who is active in defending religion both in literature and in terms of the concept of civilization. Therefore also, he is well aware of the potential of Muslims and also the various problems that surround him from time to time.. Al-Nadwî, if seen in him as a figure of a fundamentalist cleric, then in line with this is the thought and movement that he should be seen real. Among al-Nadwi's awareness as a modern-day ulema of modern reform is his maturity in analyzing the present condition of the Muslims with a comparative study of Western existence. According to al-Nadwi, the decline of Islam is based on two things, first; because Muslims have abandoned their religion; Second, because Muslims do not master science. According to al-Nadwî, these two things are sources of strength that are not separated from each other.
\end{abstract}

Keywords:

theological; Abu al-hasan; Ali al-hasani; al-nadwi

\section{Introduction}

Religion has a function to foster brotherhood especially among internal religious communities. But like the two sides of the religious coin, it has a dual role to play between integrative functions and disintegrative functions in social reality, depending on the context of internal or external relations of religious communities. (Muda in Saburi, 2020).

Long before the arrival of Islam brought by the Prophet Muhammad PBUH, humans had embraced various religions and beliefs, such as Judaism, Christianity, and pagan religions. Then Allah Almighty, sent the Prophet Muhammadiyah PBUH, who was equipped with the Holy Qur'an to bring Islam which was established on the basis of monotheism or returned to monotheism, in other words leaving behind the teachings of shirk and idolatry.

During the time of the Prophet Muhammad, Muslims were safe and secure. There is no Khilâfiah that cannot be overcome and resolved, because Rasûl is always among them to emphasize to the people what problems are the elements of conflict and difference between them, whether in religious or world affairs. This is the greatness of the Prophet's personality so that whatever is conveyed by the Prophet through the Qur'an and Hadith, they accept it sincerely after they believe that Muhammad is the messenger of Allah Almighty.

Muslims at that time devoted all their energies and thoughts to spread Islam. They never think about difficult things and turn their minds to something that is not of religious interest. All activities are aimed at strengthening the foundations of religion and raising the 
sentence of Allah "Lâ ilâha illallâhu Muḥammad al-Rasûlullâh" so that at that time it was very. quiet there were no elements of deviation from the path determined by Rasûl.

Likewise, in the caliphate after the Prophet Muhammad peace be upon him, namely Abû Bakr (632-634 AD) and 'Umar ibn Khattâb (634-644 AD) had fought all their lives against the enemies of Islam and uniting the views of friends, so there was no time to question the points of belief or aqeedah that have developed well. Small disputes that exist immediately brought by the khalifah wisely to make decisions after consultation with religious experts.

Along with theological thought journey towards various schools in Islam, thought figures in theology also emerged. Among the many existing theological figures, Abû al-Hasan Alî al-Hasanî al-Nadwî is one of the figures who received praise from his thinking by several 'ulama', such as Sayyid Quidb giving praise to the thoughts of an-Nadwî in the introduction of his book, as well as with Yûsuf al-Qarḍ̂âî yag saying:

"I recognize his personality and also his works. I found in him the heart of a true Muslim and genuine Islamic thought. I find al-Nadwî always living with Islam and for Islam. I don't think I just love him, but everyone who knows him will love him, even whoever knows him will love him more."

Al-Nadwi is the 'ulam' who has contributed to the treasures of Islamic thought in the world. In his book titled Mâżâ Khasira al-lam'lam bi Inhițâți al-Muslimîn (What is the loss of the world due to the decline of Muslims) is al-Nadwi's thoughts about history. This book is a paradigm for his other books.

Al-Nadwî describes the condition of the world before the emergence of Islam, namely the world of the sixth century AD in dire conditions. The conditions at that time were full of devastating damage and covered the whole world at that time. The damage is seen from the monotheistic religion mixed with shirk and contrary to the teachings of Islam. The emergence of paganism, understanding of idolatry, moral decay, and socio-political damage.

With his keen view of al-Nadwi's thought, he succeeded in bringing a thought that was very useful for removing and saving humanity from the modern Jahiliyah environment to the auspices of Islam. As al-Nadwî pointed out, that only Muslims are eligible to rule this world. Without Islam the world will face suffering and loss even though humans have all the sophistication and ease of life.

Based on the background of the problem above, the author intends to conduct analytical studies by raising it in the form of a dissertation entitled "Theological Thought of Sayyid Abû al-Hasan`Alî al-Hạanîi al-Nadwî.

\section{Review of Literatures}

\subsection{Background of Life and Career Abû Al-Hasan Al-Nadwî}

Shaykh Abû al-Ḥasan 'Alî al-Ḥasanî al-Nadwî is a' Ulamâ and an accomplished Islamic thinker. Al-Nadwî was born on 6 Muharram 1333 H to coincide November 23, 1914 AD in Takia Kala, Madiriyah, Rae Berily, Uttar Pardesh (northern region), India. The real name of alNadwî is 'Alî Abû al-Ḥasan ibn' Abd al-Hayyi ibn Fakhruddîn ibn 'Abd al-'Âlī al-Ḥasanî. And his message stopped at 'Abdullah al-Ashtarib ibn Muhammad żî̀ al-Nafsi al-Zakiyah ibn' Abdillah al-Mahạạ ibn al-Ḥasan al-Saba ibn 'Alî ibn Abī Tâlib ra, and his grandfather named 
Sayyid Qutb al-Din Muhammad al-Madanî (d. $677 \mathrm{H}$ ) emigrated to India in the early 7th century Hijriyah era, al-Nadwî was very fortunate to have been born and raised in a family that held fast to Islamic teachings that haq.

The family of Shaykh Abû al-Hasan 'Alî al-Hasani al-Nadwî also still have an inheritance with the Prophet Muḥammad peace be upon him. Hasan al-Sabti ibn 'Alî ibn Abî Thâlib ra.

His mother Sayyidah Khairunnissâ was a salihah woman and hafîzah was also known as a writer who wrote poetry both in Arabic or Urdu and Persian. Abû al-Hasan al-Nadwî received more guidance from the mother. From the upbringing of the mother Abû al-Hasan al-Nadwi was able to memorize the Koran thirty juz at a young age and managed to learn the basics of Arabic and Persian. From Mrs. Abû al-Hasan al-Nadwî not only received intellectual guidance but also spiritual guidance and love for the Koran. Every Friday night, recalls alNadwi, the mother always accustoms her children to recite Surah al-Kahf to be safe from world slander, and the Dajjâl as Rasûlullâh suggested.

Then Abû al-Hasan al-Nadwî continued his education to Shaykh Khalîl ibn Muḥammad al-Anhârî al-Yamânî in 1342H / 1924 AD, with Abû al-Ḥasan al-Nadwî deepening Arabic and its grammar, after Abû al-Hasan al- Nadwî already felt absorbed in the knowledge he got from his teacher, al-Nadwî went out and looked for another teacher. Then Abû al-Hasan al-Nadwî studied with his uncle, Shaykh Azîz al-Raḥmân, and several other teachers such as Shaykh Muhammad Țalhah to both of them he broadened his horizons, then afterwards specialized learning to Prof. Dr. Taqiyuddîn al-Hilâlî when he was a Lecturer at Nadwah al-lamUlamâ in 1930 AD.

Since childhood Abû al-Hasan al-Nadwî has been educated with various sciences including Arabic, theology, nahwu, poetry, Arabic literature, tafsîr, fiqh, Hadis and so on. Many of his teachers came from India and some were from Medina. At first, al-Nadwî only studied at home and in the Nadwatul al-lamUlamâ madrasa. After that al-Nadwî went higher at Lucknow University and on this campus al-Nadwî managed to get the highest score in the Arabic field.

Until the end of his life al-Nadwî had held several important positions in international Islamic institutions such as, Secretary General of Nadwatul al-'Ulamâ, India, Member of the Founding Council of the Islamic University of Madinah and the organization of Rabittah Islam Islâmî, based in Makkah, Chairperson of Rabîțah Adab Islâmî al-Alamiyah , member of the Arabic language council in Damascus, Cairo and Jordan, the Advisory Council of the Islamic University of Pakistan, and member of the founding Team of the Center for Islamic Studies at Oxford University, and others.

After almost all of his life spent on the journey of knowledge and da'wah, calling on Muslims to return to the Koran and al-Sunnah, then on Friday morning, 23 Ramadhan 1420 H / 31 December 1999 AD, al-Nadwî was picked up by Allah Almighty. , passed away to His side when he was preparing to perform Friday prayers at his residence Rae Berily Uttar Pradesh Lucknow, when he was 85 years old. Commemorating al-Nadwi's services that have been devoted to religious interests, supernatural prayers have been held in two holy lands namely at the al-Haram Mosque Makkah al-Mukarramah and at the Nabawi Mosque Madinah al-Munawwarah on the night of 27th Ramadan $1420 \mathrm{H}$. 


\subsection{External Background}

From a political point of view, the Orientalist group is a western envoy to Islamic countries with the aim of making investigations related to the customs, language, character and soul of Eastern people. In this way, the West can expand its power and influence over Muslims. Even so, there are also orient lists who make an investigation solely because of their sense of interest in science.

Introducing al-Nadwî with Western civilization not only from books, but also from his experiences in visiting Europe and America which he did several times al-Nadwî was known for his mastery of philosophical scholarship, in fact he had been asked to deliver public lectures with Islamic themes and modern philosophy.

Al-Nadwî saw in his life the power of Western civilization which hegemony the way of thinking of Muslims. Armed with his deep understanding of Islam and his study of Western civilization, al-Nadwî became one of the prominent Islamic figures who carried the mission of the Qur'an and al-Sunnah into the midst of modern life.

According to al-Nadwî, Muslims now face "ignorance" of thought or precipitating intelligence of reason that afflicts Islamic scholars or centers of Islamic study. Likewise, it is rare to find 'Ulam' who can convince the young generation about the superiority of Islam and the immortality of religious teachings in living life and expose the veil of the weaknesses of Western civilization.

Al-Nadwî uses the propaganda manhâj based on the Koran then kemudianadis and the sirah and the stories of the Companions. This is clearly evident in his book Rawâ'i min Adab al-Da'wah where al-Nadwî takes examples of the da'wah of the Prophets sourced from the Koran and Hadis. Besides that al-Nadwî acknowledged that the manhaj might differ from one place to another because preaching must also look at environmental conditions. Therefore, the da'wah that is memorable is the da'wah that touches the existing reality. AlNadwi also suggests understanding the Koran in depth, the history of da'wah and religious figures and Islamic customs.

Al-Nadwi has succeeded in opening a narrow view of the leaders of the Islamic world who assume that the material wealth possessed by European society is everything while they have been bankrupt in terms of thought and spirituality. With his keen point of view, Shaykh Abû al-Hasan î Alî al-Nadwî managed to bring a useful thought to expel humanity rather than the confines of life hidup modern Jahiliyah 'to the auspices of Islam.

After the end of British rule in the city of New Delhi (1858) many schools have been established, Islamic boarding schools are found in several cities including; New Delhi, Lucknow, Agra, Ranpur, Balkram, Hairabath, Junpur, Haidrabath, centers of Islamic education.

In the midst of the political turmoil in education that occurred in India, at that time alNadwi was alive. Feel the harsh currents of modernization and also feel the struggle to maintain the existence of Islamic teachings. Although al-Nadwi was raised in a situation of European colonial expansion, the situation of al-Nadwi's development of thought did not affect his thoughts and culture for his life, and al-Nadwi was far from destructive.

Furthermore, even al-Nadwi still adheres to the values of religion and jihad because Islam has taught that the last message of God must be eternal, because he is a true treatise 
besides being a heretic. Because Muhammad PBUH, bin Abdullah, bin Abdul Muttalib al Hasyimy al Quraisy al-Arabi as the final Apostle, the priest of all human beings and savior in both the world and the hereafter.

The first work al-Nadwî wrote in Arabic was a plan published in the magazine "AlManâr" published in Egypt by Shaykh Rasyid Ridhâ in 1930 CE. From that time al-Nadwî continued to work until the end of his life, al -Nadwî continues to write and work on his own sometimes with the help of others in the moments of his eyes.

\section{Discussion}

\subsection{Abû Al-Ḥasan Thought 'Alî Al-Nadwî about Theology a. Al-Nadwî's Thinking About God}

The main values (teachings) in a religious teaching are located in the aspects of the concept of monotheism. These divine principles and values which in turn become an indicator of a religion and become a measure of the security of a teaching that each religion seeks to maintain. Not only in Islam, have other religions outside of Islam also had different divine concepts with each other's truth.

Al-Nadwi, with the existence and breadth of his knowledge, not least took the same role as the other Ulemas, including in building the concept of God, both in terms of ushûl and in terms of his approach. Based on his educational background, genealogy of his descendants, and following his works, it can be concluded that in the case of ushûl al-Nadwî was a follower of Asy'ari'ah and an adherent of the Hanafi school of thought.

In the concept of God, what is most important in the understanding offered by alNadwi lies in the aspect of the path to the divine. If the scholars use the term "Sufism" as one of the terminologies of the path to the divine, then al-Nadwî "rejects" the term Sufism by offering the concept of inner fiqh, tarkiyah, and ibsan.

In general, al-Nadwî in introducing the concept of ihsan is not different from the other Ulams'. According to al-Nadwî, with a deep understanding of the ihsan, a servant can draw closer to Allah Almighty, by taking the right path without being integrated with religious practices that are isrâ'iliyyat. Although not using the term "Sufism" in interpreting "practice" closer to Allah, al-Nadwi does not mean disagreeing with the teachings of Sufism as a whole. Even in some of his books he gave the highest appreciation of the movement of Sufism as one step to avoid the understanding of materialism into Muslims as embraced by the West.

In this case, al-Nadwî narrates the Hadith of the Messenger of Allah, which is narrated by 'Umar bin al-Khattâb:

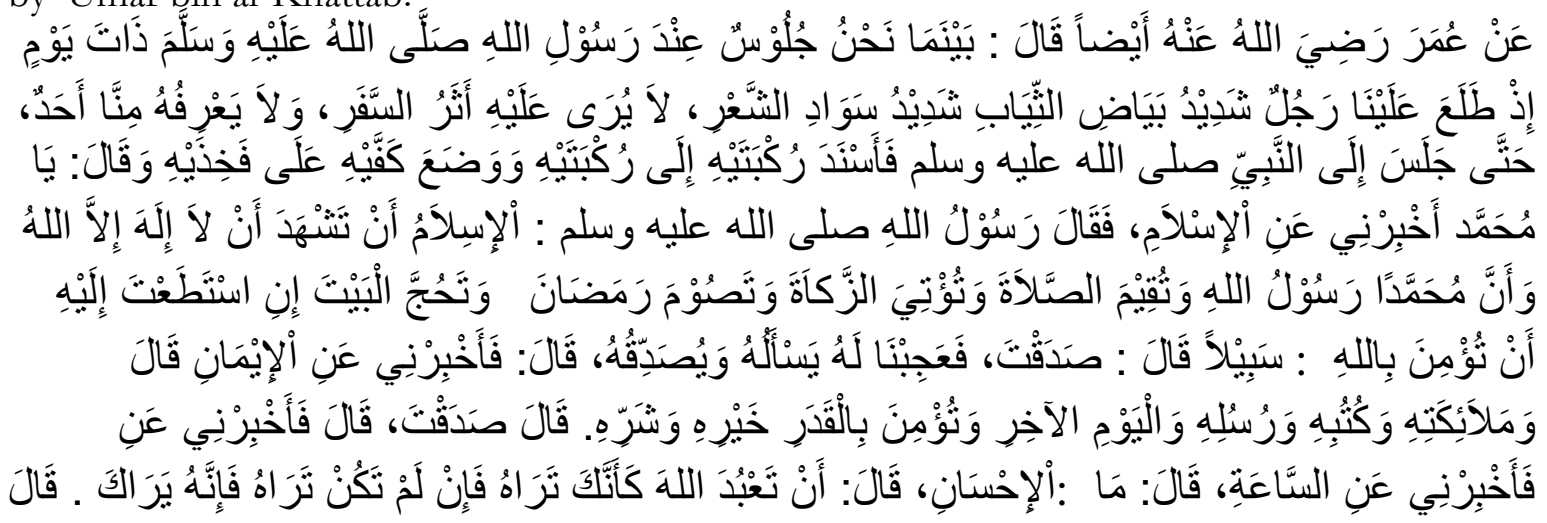




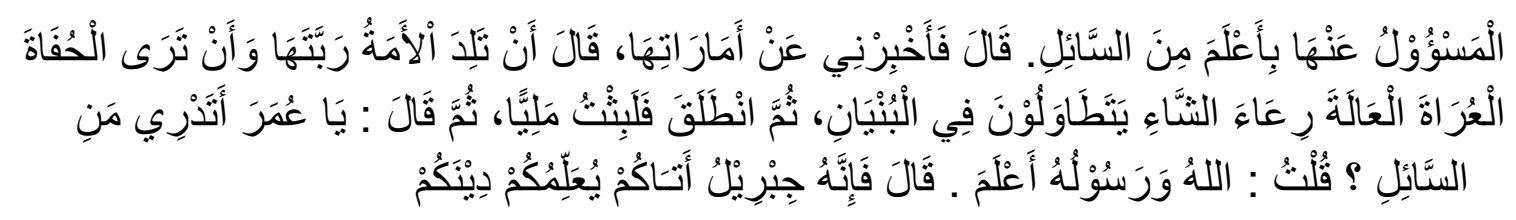

From Umar r.a. he said: "When we sat beside the Messenger of Allah., one day suddenly a man who wore a very white shirt and very black hair, did not see him traces of a long journey and there was no one among us who know him. Until then he sat in front of the Prophet and put both his knees on his knees (Rasulullâh peace be upon him) and said: "Yes Muammad, tell me about Islam?", Then said Rasulullah saw. worshiped) besides Allah, and that the Prophet Muhammad is the messenger of Allah, you establish prayers, perform zakat, fasting Ramadan and go on pilgrimage for those who are able ", then he said:" you are right ". We were all surprised, he who asked him also confirmed. Then he asked again: "Tell me about faith". Then he said: "You have faith in Allah, His angels, His books, His Apostles and the last day and you have faith in good and bad destiny", then he said: "You are right" . Then he said again: "Tell me about ihsan". Then he said: "Ihsan is that you worship Allah as if you saw Him, if you do not see Him then He sees you". Then he said: "Tell me about the Day of Judgment (when it happened)". He said: "Those who are asked do not know better than those who ask". He said: "Tell me about the signs", he said: "If a servant gives birth to his master and if you see a man with bare feet and breasts, poor and a shepherd, (then) vying to raise his building", then that person passes and I stayed for a while. Then he Rasulullah said: "Do you know who is asking?" I said: "Allah and His Messenger know better". He said: "He is Jibrîl a.s who came to you (intend) to teach your religion".

Understanding that can be taken from the concept of ihsan in the above Hadith is, that a worship requires a "perfection" or carry it out with the "best". Thus, in the terminology of Islamic religion, ihsan means someone who worships Allah as if he sees Him, and if he is unable to imagine seeing Him, then that person imagines that Allah actually sees his actions.

The key words which are then "underlined" by al-Nadwî are the words "worship Allah" and "Allah see". These two keywords then become the development of every charity practiced by every Muslim. Worshiping Allah Almighty, has a very broad meaning, not only limited to worship mahdhah such as prayer, fasting, alms, hajj; but more than that, al-Nadwi gives a very deep meaning of the word الله ت ع بد ان more than just performing the mahdhah worship, but it also covers all aspects of human life.

In this case, if a human being has a deep understanding of the matter of ihsan, understands his position as a servant and knows and believes that Allah, always knows everything he does, then by himself the human being is guided in the right direction, starting from the words, deeds, and attitude.

In describing the concept of the divinity of al-Nadwî, then what will be found in each of his writings and lectures is a study of the interpretation of "god" itself. Al-Nadwi on a certain side may be "not paying attention" to the concept of God in the morphological order, but rather examines the realm of terminology and axiology in worshiping Allah.

\section{b. Al-Nadwî's Thinking About Prophethood}

Prophethood, according to Ibn Sina, is a high soul (spirit). The Prophet is a chosen human who has advantages over other humans. Having a miracle that aims to invite people to renounce polytheism, establish rules for the happiness of humanity, lead people to understand the good system. 
Although Prophets and Apostles are like ordinary people, but he has the privilege because he obtained the highest sense from God called al-hadas. Al-hadas has a sacred power called al-quwwah al-qudsiyyah. As for the meaning of al-hadas in philosophical giving is the divine radiance obtained by the Prophets and Apostles so that they can deal directly with 'aql (Allah) without going through human effort itself. This power is what distinguishes the Prophet and Apostle from other humans. A special power and only obtained by the Prophet and Apostle. Because of this power also the Prophet and the Apostle can receive revelations from Allah to be conveyed to mankind and so that they act and act according to that revelation.

In prophetic philosophy it is understood that the Prophet or Apostle only conveyed Allah's commands in general and brought news that had never been heard and seen. The command of worship to Allah aims to enable humans to free themselves from the attachment of the material world, turn away from other than Allah with strong faith, understand the obligation by following divine wisdom in the commission of a Prophet and Apostle. so that it ends up being a driving force to achieve happiness after the spirit is separated from the body.

Instinctively, humans can know some good and bad deeds with their minds. Human resourcefulness is not enough to know ways that can show the way to the salvation of the world and the hereafter. Therefore humans, humans need a human being sent by God who delivered His Shari'a so that humans can achieve salvation without passing through actions and paths that endanger it. The presence of Prophets and Apostles is a primary human need because reason cannot fulfill it. The Prophet and Apostle have six main tasks, namely:

1. Give guidance to humans so that people know Allah (ma'rifatullah). Delivering the attributes of Allah that can facilitate human understanding of His Greatness, in the easiest way.

2. Delivering the news that Allah threatens people who disobey Him and provide good news for those who obey Him.

3. Teaching noble morals to humans that are useful for humans themselves and for others, such as honesty, not lying, generous, and so on.

4. Teach the procedures to glorify Allah and fulfill the obligations placed on God by humans, and worship Him in various forms perfectly.

5. Establish legal provisions (hudûd) and rules that must be obeyed by someone in relation to each other, such as the provisions of adultery, murder, and so on. These provisions aim to uphold justice which can guarantee the security of the country and its inhabitants. In connection with this task, the Prophet and Apostle functioned as judges or legislators.

6. Explain the right ways what must be taken by humans in their worldly lives, such as the need to actively work, and carry out various forms of obligation.

Based on the duties of the Prophets and Apostles above, it can be stated that the religion of Islam is a religion for all humanity. Islam guarantees the happiness of the lives of those who embrace it, and carry out the teachings of Islam to its fullest. Position of the Apostle for humans is like the position of reason and conscience for humans who can distinguish between good and bad, or what is right and wrong. If humans are wrong in distinguishing between good and bad, or which is right and which is wrong, then it happens because of man's indifference to the use of reason and conscience, which is then controlled by hatred, greed, and enmity.

Therefore, there is chaos, error, fanaticism in schools and groups. All this happened not because of religion, but because religion was not carried out properly as a result of errors in understanding and appreciation. 
Based on the description above that prophetic philosophy is understood that the Prophet or Apostle only conveyed Allah's commands in general and brought news that had never been heard and seen. The command of worship to Allah aims to enable humans to free themselves from the attachment of the material world, to turn away from other than Allah, with strong faith, understand the obligation by following divine wisdom in the commission of a Prophet and Apostle. So that it ends up being a driving force for happiness after rûh is separated from the body. Position of the Prophet and Apostle for humans is like the position of reason and conscience for humans who can distinguish between what is good and what is bad, or what is right and what is wrong.

\section{Conclusion}

Al-Nadwî is a great Ulama with a very complex socio-cultural background, born during the colonial era and struggling in a period of development transition and national change that makes al-Nadwî rich in various experiences of obstacles, be they social, cultural, or religious obstacles. Therefore it is not surprising that al-Nadwî grew up as a Fundamentalist Ulama. He is a Ulama figure who is active in defending religion both in literature and in terms of the concept of civilization. Therefore also, he is well aware of the potential of Muslims and also the various problems that surround him from time to time.

Al-Nadwî, if seen in him as a figure of a fundamentalist cleric, then in line with this is the thought and movement that he should be seen real. Among al-Nadwi's awareness as a modern-day ulema of modern reform is his maturity in analyzing the present condition of the Muslims with a comparative study of Western existence. According to al-Nadwi, the decline of Islam is based on two things, first; because Muslims have abandoned their religion; second, because Muslims do not master science. According to al-Nadwî, these two things are sources of strength that are not separated from each other.

\section{References}

'Abd al-Salâm Sa'îd al-Azharî, al-Imâm Abî al-Hasan al-Nadwî wa Manhajihi fî

Adian Husaini and Nuim Hidayat. (2002 ) Islam Liberal: Sejarah, Konsepsi, Penyimpangan dan Jawabannya, Jakarta: Gema Insai Press.

al-Nadwî. (1981). Baina ad-Din wal Madaniyah, cet 2, (Beirut: Muassasah ar-Risalah)

Anton Bakker and Achmad Haris Zubair. (1992). Metodologi Penelitian,Yogyakarta: Kanisius.

H. Fachrur Razy D (Ed). Ilmu Kalam: Buku Proyek Pembinaan Perguruan Tinggi agama IAIN Sumatera Utara Medan,T.A 1985/1986M

Ismail R. al-Farûqî. (1989). Islam and Culture. Terj, Bandung: Mizan.

M Taib Tahir 'Abd Mu'în. (1975). Ilmu Kalam, Jakarta: Penerbit Wijaya.

Martin Van Bruinessen and Julia Day Howell [ed]. (2007). Suifsm And The Modern In Islam, London: IB Tauris.

Muḥammad Ijtabâ' al-Nadwî, Abû al-Hasan 'Alî al-Hasanî al-Nadwî al-Daiyah al-Ḥakîm wa alMurabbî al-Jalîl, Damaskus: Dâr al-Qalam, cet. ke-1, 1421H/2001M

Muhammad Țâriq Zubair al-Nadwî, Samâḥhah al-Imâm ad-Dâ‘iyah al-Syaikh Abî al-Ḥasan 'Alî al-Hasanî al-Nadwî, India: Maktabah Locknow, cet. Ke-1, 1419H/ 1998 M

Saburi, A. (2020). Contribution of NEO Modernism Thoughts on Islamic Thoughts in Indonesia. Budapest International Research and Critics Institute-Journal (BIRCIJournal). P. 1443-1452. 